\title{
Shift away from NASA
}

\section{Washington}

THE White House has decided to look outside NASA (the National Aeronautics and Space Administration) for advice on the proposed manned mission to Mars, a shift that may be the first sign of a growing power struggle between the space agency, the vice-president-led National Space Council, the aerospace industry and government research laboratories over who shall take part in and plan the massive two-decade project.

In a speech to the American Astronomical Society in Washington earlier this month, Vice President Dan Quayle announced that he had asked the Aerospace Industries Association and the National Research Council independently to review proposals for going to the Moon and Mars in the next century.
"The hypothesis, which remains to be demonstrated, is that there are a lot of ideas out there that NASA has rejected because of institutional bias", says George Washington University space policy analyst John Logsdon, a Space Council adviser.

The decision indicates a diminishing White House confidence in NASA. Late last year, the agency submitted to the Space Council a preliminary plan outlining five similar scenarios for the mission, ranging from 18 to 25 years in duration. But critics of the plan say that it reflects NASA's commitments and allegiances to existing projects and relationships more than innovative thinking about longdistance space travel. All five NASA options, for example, depend heavily on the Space Station, a troubled project that

\section{Cetus battles with Du Pont}

\section{Washington}

WITH the recent issue of a broad patent covering Taq DNA polymerase to Cetus, the California-based biotechnology corporation looks set to dominate the lucrative US market for PCR (polymerase chain reaction) based products. Cetus has been quick to protect its patent rights to the PCR technique, which was first fully described only five years ago. This is the fourth US patent awarded to Cetus for PCR and related enzyme technology another 40 are pending.

The US patent for Taq DNA polymerase - the thermostable enzyme that catalyses the DNA amplification technique PCR - was issued on 26 December. It covers the full-length enzyme, as purified from the bacterium Thermus aquaticus or that produced by genetic engineering. Peter Staple, associate general counsel for Cetus, says the Taq DNA polymerase patent effectively bars anyone from "making, using or selling" the enzyme in the United States.

News of the patent will alarm the many US biotechnology companies that manufacture $T a q$ DNA polymerase and Taqbased products. Staple says that Cetus has already been approached by several companies keen to produce under licence and, although this may be permitted for "certain" applications, requests would be reviewed case by case.

Cetus will not disclose its revenue from Taq DNA polymerase, which is marketed through the Perkin-Elmer joint venture, but says it is one of its largest selling molecular-biology reagents. The joint venture with Perkin-Elmer, which includes a thermal cycler used to automate PCR, should earn Cetus $\$ 60$ million a year by the mid-1990s.

While the latest patent will strengthen Cetus's overall position regarding PCR, the company is still engaged in a bitter dispute with the biotechnology giant, Du Pont. Last August, Du Pont filed a law suit against Cetus challenging the validity of its two key PCR patents which cover the PCR process and the detection of PCR products. Du Pont cites two papers suggesting a possible method for DNA amplification published more than ten years before Cetus first described PCR (see Nature 342, 9; 1989).

Du Pont has made a "substantial investment" in the development of PCR-based kits for the diagnosis of human diseases. It has been unable to obtain a licence from Cetus, which has licensed all diagnostic uses of PCR to Hoffmann-La Roche. The suit is seen as a pre-emptive strike by Du Pont which is under "reasonable apprehension" of being sued by Cetus for infringement of the two PCR patents.

Hoffman-La Roche, which stands to gain an estimated $\$ 600$ million a year by the mid-1990s from the sale of PCR-based kits and assays, has petitioned the patent office for a "re-examination" of the two patents. Staple says this legal provision determines whether there is a question of patentability in claims of prior art, and usually results in an upholding of the original patent.

The court case between Du Pont and Cetus is set for 7 August. But Du Pont's plans to go ahead with the launch of its first PCR-based product, an HIV-1 test kit, at the end of this month is likely to spark a new wave of controversy and yet more litigation.

Diane Gershon is in dire need of a compelling mission such as the Mars project.

"To no one's surprise, NASA came up with a plan that was essentially aimed at keeping the contractors employed", says John Pike, space policy analyst for the Federation of American Scientists. The Space Council's decision to widen the planning process is a sign that the NASA plan is "dead in the water", he says.

Some members of the aerospace industry are privately hopeful that Pike's interpretation is correct. Although many aerospace companies have links with NASA, the Defense Department has historically been a far richer source of funding. With major budget cuts planned in defence programmes, however, industry executives are eager to find a non-defence market for their high technology. One solution would be to strengthen their ties with NASA. But NASA loyalties are well established.

The Space Council's decision may offer the aerospace industry a good chance to get in on the ground floor. The Aerospace Industries Association says it will look primarily among its members for new ideas to bring to the Space Council. A report is due by the end of March.

For the defence-orientated national laboratories such as the Department of Energy's Lawrence Livermore and Los Alamos facilities, the thawing of the cold war has likewise left many laboratory scientists enviously eyeing the Mars mission. Both laboratories are intimately involved in the Strategic Defense Initiative, for which funding seems set to plummet.

Livermore founder Edward Teller and his protégé Lowell Wood have both spent time talking to the Space Council about proposals for Mars. Quayle is said to have been impressed by one idea of Wood's for using inflatable Kevlarcovered balloons for space travel and both Mars and Moon bases. The doublewalled 5 metre $x 15$ metre structures could be stowed compactly until needed, Wood says, greatly simplifying the process of establishing living quarters or storage space. Although Wood acknowledges that the technique carries some risk - the balloons might pop - he claims the technique could cut the project's cost by an order of magnitude.

That idea and others gathered by NASA will be the focus of the NRC study. A panel headed by former White House science adviser Guyford Stever will prepare a report by the end of February. Some speculate that the hurried timetable is to put together a viable plan in time for the planned US-Soviet summit this spring.

Gorbachev is expected to suggest going to Mars together. With a plan that has come from the National Research Council, the Aerospace Industries Association and NASA, Bush may finally be able to agree. G. Christopher Anderson 